\title{
Descriptive Analysis of Writing Composition from the Ideas to the Paragraph
}

\author{
Titik Nurrohmah \\ MTs Negeri Tanon \\ Waduk Ketro, Tanon, Sragen, Central Java, Indonesia \\ nurrohmah@yahoo.com
}

\begin{abstract}
What are the ways to discover the ideas to write? How to organize the ideas into the paragraph? To answer these questions, the writer conducted a qualitative research that the object of the research is writing composition on the discovering the ideas and organize it into paragraph. The writer used descriptive method. For obtaining the data, the writer used library method as the instrument and used secondary sources that constituted secondhand information, such as reference book. Meanwhile, in analyzing the data, the writer used an expository writing. There were several ways in discovering ideas as the result of this study. Those included remembering experience, getting people opinion about particular subject by giving evidence, finding a great deal by asking other people about their experience and going to the library to get any ideas. Whereas, to organize the ideas into paragraph, someone has to do some steps, such as selecting a subject, planning a composition and making an outline.
\end{abstract}

Keywords: Writing Composition, Idea, Paragraph

\begin{abstract}
Abstrak
Bagaimana cara menemukan ide untuk tulisan? Bagaimana membuat ide menjadi paragraf? Untuk menjawab pertanyaan - pertanyaan tersebut, penulis melakukan penelitian dengan objek penelitian yakni karangan tertulis untuk menemukan ide dan membuatnya ke dalam sebuah paragraf. Penulis menggunakan metode deskriptif. Untuk memperoleh data, penulis menggunakan metode pustaka dan menggunakan sumber kedua yang merupakan informasi kedua seperti buku referensi. Sementara itu, untuk menganalisa data, penulis memberikan penjelasan tertulis. Hasil dari penelitian adalah adanya beberapa langkah dalam menemukan ide, diantaranya adalah mengingat pengalaman pribadi, meminta pendapat orang
\end{abstract}


lain tentang suatu persoalan atau pengalaman mereka, dan mengunjungi perpustakaan untuk mendapatkan ide. Sedangkan untuk membuat ide menjadi paragraf, seseorang harus melakukan beberapa langkah seperti menentukan persoalan, merencanakan sebuah karangan dan membuat kerangka karangan.

Keywords: Karangan tertulis, ide, paragraf

\section{Introduction}

Instead of listening, reading, and speaking, writing is the highest level of language skill that should be mastered by students. Writing in the sense of verb "write" means (a). Letters or other symbols (e.g. Ideographs) on a surface, especially with a pen or pencil on paper, (b). Put down (on paper) by means of Word. (Horby, 1987: 996)

To be literate in the native language implies the ability to read and to write. This approach to native-language learning has transferred to the foreign language classroom. Writing exercises keeps students busies and outs of mischief. Conventional writing exercises are easy to construct. Rivers (1981: 291) in his book teaching foreign-language skill states:

"At this stage, it may be well to recall two facts often ignored by language teachers, who traditionally have expected students to write something as a demonstration of learning: first, that many highly articulate person express themselves very inadequately in writing in their native language. Second, that only a minority of the speakers of any language acquire the skill of writing it with any degree of finesse, and then only after years of training in school and practice out of school."

In accordance with Warriner (1977: 332), writing is chances to communicate the thought in the most effective way possible, just to carry out the written. This may result in composition that are lifeless, dull and worth very little. Empty writing is bad writing. 
Unfortunately, examination papers in composition the world over are, with few exceptions, disappointing. Many college and university students with four, five, even six or more years of study of another language behind them are still unable to express themselves in a clear, correct, and comprehensible manner in writing. All writer-students' writing papers for their college courses, business people communicating ideas in reports and memos, journalists composing news stories, even novelists writing yearly novels-know these basic frustrations.

Writing clear and simple prose is difficult, even for experienced writers. It is slow and laborious process. So, if someone is humble for the right word, get lost in tangled sentences, fall silent in the middle paragraph does not despair. Everyone who writes has this trouble. It is as well to remember that not all students have already flow of ideas when asked to write. (Alto, 1984: 5)

One of the primary aims of this research is to offer the writer way to discover ideas before they write their composition. The best way to begin is with an overview of the writing process and the next. It will discuss about an expository writing that every student must understand in order to begin and progress through the process.

Regarding the background above, the writer would like to figure out these following questions: (1) what are the ways to discover the ideas to write? (2) how to organize the ideas into the paragraph?

\section{Compositions}

According to Oshima (1988: 4), a composition is a piece of writing that has more than one part. It is divided into three parts; a beginning, middle, and an end. The beginning is called introduction, the middle is called the 
body, and the end is called conclusion. The introduction and the conclusion are usually one paragraph.

While the paragraph consists of sentences closely related in meaning. Further, Warriner (1982: 333) clarifies that composition is made up of related paragraphs. Like the paragraph, the composition focuses on a single idea, which is often stated near the beginning.

\section{Paragraph}

According to Alice (1988:4), "Paragraph is a group of related statements that a writer develops about a subject. Each paragraph is a separate unit marked by identifying the first word from the left-hand margin, or by leaving extra space above and below the paragraph." Therefore, paragraph is a set of related sentences that work together to express or develop an idea. Further, Crimmon (1984: 192) explains that although it may stand on its own and in some writing situation a writer needs but a single paragraph to fulfill his or her purpose - a paragraph is usually a unit in complete piece of writing. This function as a unit of development in that it organizes and advances the writer's idea's that is, it helps develop the writer's thesis, in the case of narrative or descriptive writing, carries forward a story or provides significant details.

\section{The Stage of Writing Process}

Good writing has sharpness, vividness, and clarity. There are several ways of looking closely, of writing process.

\section{Choosing a Topic}

A composition of the kind someone will be writing this is still a short piece of writing. Avoid choosing a topic so large that one's would have to write a book to do it justice. There are some steps to choose a topic. The first one is choose the subject. Knowing the subject is the first principle of good 
writing. The second one is limiting the subject. Once someone has found a subject to write about, he must decide whether it is too big to handle in the time and space he has to work with. Big subject are not easier to write about than smaller ones. The third one is adopting the subject to the reader. Someone must adjust the topic and the content to the audience for which he writes. The last one is determining the purpose. After limiting the topic, one's must consider the purpose of his composition. Taking the particular attitude toward his subject will help someone defines that purpose.

\section{Planning the Composition}

Planning is any orderly produce used to bring about a desired result. As the first stage in the writing process, planning is a series of strategies designed to find and produce information in writing. When someone begins any writing project, he needs to discover what is possible. He needs to locate and explore a variety of subjects. He needs to invent alternative ways to however mundane or unsettling, in order to select and create the substance out of which he will shape his subject.

\section{Drafting}

Drafting is a procedure for drawing up a preliminary sketch. As the second, in the writing process, drafting is a series of strategies designed to organize and develop a sustained piece of writing. Once planning has enabled someone to identify several subjects and encouraged you to gather information on those subjects from different perspectives, he needs to determine what he can best accomplish in writing. Someone needs to select one subject and organize his information about it into meaningful clusters. Then, someone needs to find connections among those clusters and discover the relationship that links the connection. 


\section{Revising}

Revising is procedure for improving or correction a work in progress. Revising is a series of strategies designed to re-examine and re-evaluate the choices that have created a piece of writing. After someone has completed his preliminary draft, he needs to stand back from his text and decide what actions would seem to be most productive. Someone may have to embark upon global revision - a concerted effort to perfect the smaller elements in a piece of writing he has already created.

\section{Research Methodology}

This research is the qualitative research. Moleong (1983: 3) affirms that "Qualitative research is a research of which the data in the forms of written or oral word are descriptively analyzed. In this research, object of the study is writing composition on the discovering the ideas and organize its into paragraph. Related this research, the writer uses descriptive method in which this method is to describe what actually happens in certain conditions. While the data resources, the writer uses secondary sources that constitute secondhand information, such as reference book.

To collect the data, the writer uses the library method as her instrument. Moreover, to make this research clearly, the writer draws her step of research as follow: 


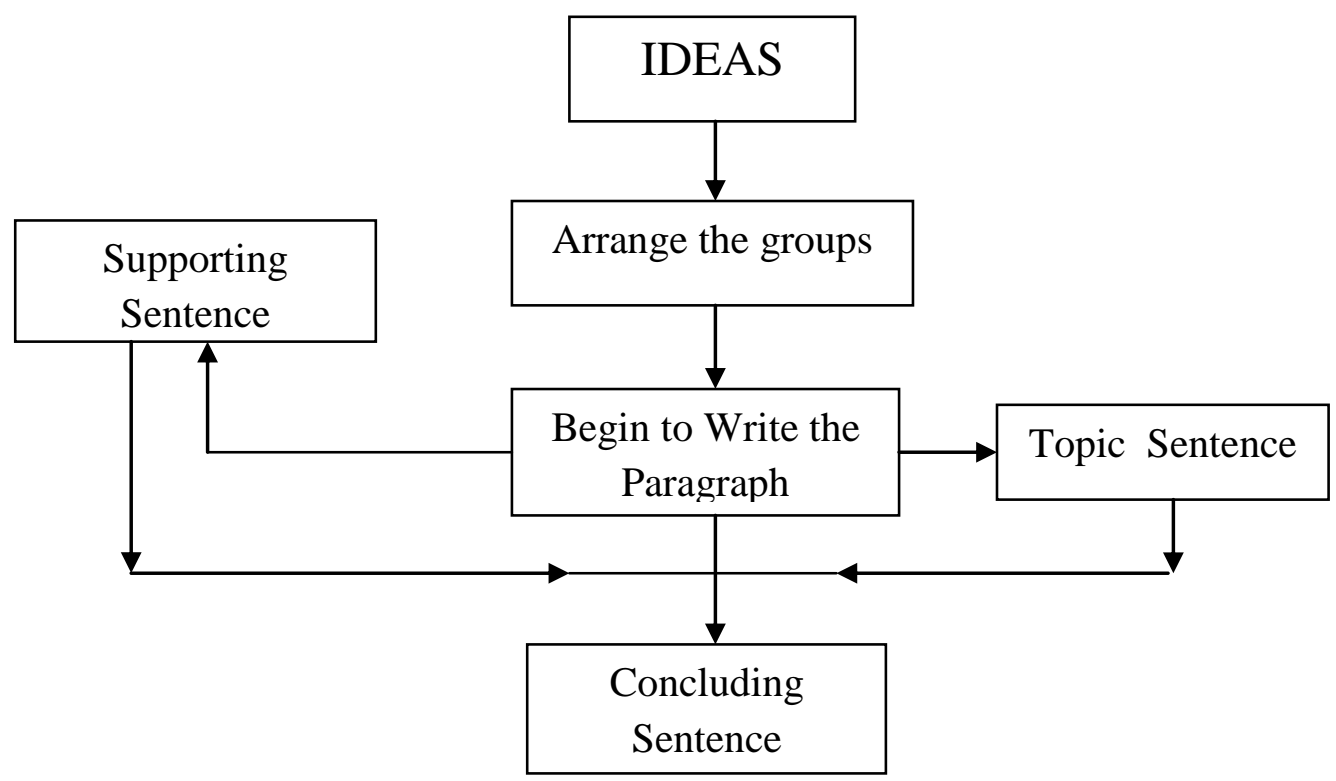

In analyzing the data, the writer used an expository writing. The steps of data analysis are (1) discovering ideas, (2) choosing the subject by arranging and classifying the ideas into the group that seems to go together, (3) beginning to write the paragraph. In writing the paragraph, (4) identifying the function of each sentence as topic sentence, supporting sentence and also concluding sentence, and (5) drawing the unity and coherence paragraph.

\section{Discussion}

The writer presented the most important part of thesis, the result of the data analysis. It will be explained more in detail in the following.

\section{The Ways for Discovering Ideas}

Viki (2003: 31) claims that idea is a thing cannot be influenced by money. You will get a great deal ideas. One important thing that you have to do is giving attention to the ideas.

What someone knows from himself experience and others experience is the idea to write composition. But there are another sources and information 
for discovering the ideas, such as the people opinion about particular subject giving evidence. In expository writing, people needs to give the facts and impressions that lead the people to his opinion, in order to make it real to someone else.

Example :

Opinion : Children should believe in tooth fairly

List of evidence : It makes losing teeth exciting

It is run to believe in an invisible friend

It makes children feel they are special

It gives kids something to look forward to

The next method is to whom does someone ask? Now he can find out a great deal by asking other people about their experience. Many things he takes for granted are really brand-new in our history. Older people that he knows lived in a very different way when they were his age.

What can a police officer tell? He or she can tell:

What it is like to be a police officer

What kinds of crime a police officer handles

What the difference is between juvenile and adult crime

How the police station works

Why he or she became a law enforcement officer

There are other people one's can talk to. Think about these people and list all the information one's might get from each one. Share all the lists in class and see how many ideas everyone had. They are:
1. Janitors
7. Social workers
2. Secretaries
8. Firefighters
3. Letter carriers
9. Playground directors
4. Neighbors
10. Conductors
5. Hospital aid
11. Other students
6. Teachers
12. Scout leaders 
When someone asks people to tell him about something in detail, he is having interview. An interview is meeting between a reporter and someone who gives information to this sense, when someone asks questions he becomes a reporter.

It is not easy to interview as he might think. It takes a great deal to practice. One's has had some practice in asking questions. There are some tips in interviewing. Those include (1) have a list of questions (2) always ask "how" and "why" when an answer is given (3) If someone gets a short or impractical answer, don't give up (4) Do not let the interview get off the point (5) Do not feel limited by the questions you have prepared (6) Listen carefully and treat the person that interviewing with respect (7) Be sure to plan enough time (8) Plan the interview time so that it's convenient.

For example: interviewing family members, the topic is "What do you think about the rule, "you should never lie?" Andrew interviewed about this topic to his brother Kevin.

Kevin : Do I believe in this rule? Yes. What do I think it means? I think the rule is not just referring to telling lies to someone else, it can be arguing...

Andrew : Even when you know you are wrong.

Kevin : Exactly or when people are always getting defensive. For instance, it could be that one person owns a thing of a specific brand name and someone else says it is bad; maybe someone owns a certain stereo and someone else says he should have gotten another kind. The person with the stereo gets very defensive, when really objects were never meant to be extensions of human beings. Attacking the object is not attacking the person. I consider this kind of arguing one from the lying.

In order to remember one's result of interview, someone has to take a note during interview. It is important to choose information that answers the questions. It is also a good idea to write down one or two important words or 
phrases that remind one's of several sentences, so the someone will not forget information he has heard.

Everyone will work out his or her own kind of shorthand. A few words that remind someone of each answer may be all he needs. Whatever from one's chooses for his notes, remembers that they have to be useful. These are some tips that will help someone to take notes in an interview. These are (1) write the information that answers the question and (2) pick one or two important words or phrases that remind someone of several sentences.

The next step to get the sources is going to the library. Someone can find the book that she/ he want by looking at card catalogues. Card catalogues are lists of the materials in the library. However, sometimes cannot find the he is looking for. There are some hints to help someone when he cannot find what he needs in the library. They are (1) Look in the card catalogues under the title of the book or the author's name (2) Look in the card catalogue under the subject (3) Notice the number in the upper left-hand corner of the card in the card catalogue (4) Ask the librarian where the section of reference books can be found (5) Remember that the librarian is the best guide.

Another good source is one's daily paper. It is good idea to look at the paper every day. It has articles on news from around the world such as food community, affairs, books, and other subjects.

\section{Organizing the Ideas into the Paragraph}

\section{Select a Subject}

a. Choose a subject that someone knows something about

Such a subject, which someone can write about from his own experience, is an excellent possibility for a composition. If someone 
stops to think about it, there are a number of things that he knows about. Someone's whole experience is raw material for compositions.

b. Limit the topic

Someone' composition will not succeed unless its subject is well chosen and well developed for the reader. When he has thought of a subject, therefore, it is essential that he consider whether it is manageable in the number of words he has in mind. For example, stamp collecting may provide him with an idea for a composition, but the whole subject is too large. On the other hand, a composition telling how to get started with a stamp collecting is a limited topic just right for 300 words for composition.

c. Remember the purpose of composition

The specific purpose that someone has in mind should guide him in limiting the topic, and then in selecting ideas and planning the composition.

\section{Planning a Composition}

Since a composition is usually longer and more complicated than a paragraph, there is even more need for a careful plan.

a. Make a list of ideas

Once someone has chosen a topic, jot down ideas as he occurs to him. At this stage, do not try to organize the ideas. We can make a list any details or ideas that may be related to the topic. After completing the list, any ideas that are not closely related to the topic can be eliminated.

For example:

Topic : Beginning a stamp collection

Purpose : To explain how to collect and display stamps

\section{Educational value}


Family mail

Hobby stores

Removing stamps from envelopes

Fun of watching collection grow

Learning location of countries

Appreciating of beauty

History of postage stamps (eliminated because it does not contribute to purpose of composition)

Learning about people and customs of foreign lands

Mounting stamps an album

Supplies, tongs, hinges, album

Post office

Stamp packets

Approval sheets

Valuable stamps (eliminated because a beginning collector would

not ordinarily try to acquire valuable stamps)

b. Group the ideas under headings

The next step is to begin grouping closely related ideas together.

To do this, he must consider whether two or more ideas have something in common-whether there is a larger idea that includes them. For example, here are six of the ideas from "Beginning a stamp collection".

1) Fun of watching collection grow

2) Removing stamps from envelopes

3) Learning about people and customs of foreign lands

4) Appreciating beauty of stamps

5) Learning locations of countries

6) Educational value

A quick glance tells us about that some of these ideas are related and some are not. There is an obvious connection between numbers 1 and 4 , both of which involve pleasure or enjoyment. A similar connection exists between 3,5 , and 6 , all of which have something to do with the educational aspect of collecting stamps. Only 2 do not combine with a related idea.

Making an outline 
The purpose of the outline is to show all of the ideas and headings that will go into the composition in order someone will take them up and in the relation he has to each other. The major topic for "Beginning a stamp collection" may be arranged in order of time, certainly the idea of "acquiring stamps" belongs before that of displaying stamps", and reasons for collecting stamps" comes before either. The complete topic outline on this subject would look something like this:

Title : Beginning a stamp collection

Purpose : To give reasons for collecting stamps and to show how to get started.

I. Reasons for collecting stamps

A. Pleasure

1. Fun of watching collection grow

2. Appreciating beauty of stamps

B. Educational value

1. Learning about people and customs of foreign lands

2. Learning locations of countries

II. Sources for the collector
A. Family mail
B. Post office
C. Hobby stores
D. Stamp dealers

1. Packets

2. Approval sheets

III. Stamp display

A. Supplies

1. Album

2. Hinges

3. Tongs

B. Procedure

1. Removing from envelopes

2. Mounting in Album

IV. Specialization

Notice that a fourth main idea has been added to provide a conclusion for the composition. Someone has told how to start a collection; he wants to end giving the reader some ideas of a more advanced kind of collecting. 


\section{Conclusion}

There are several ways in discovering ideas; what do the students know from themselves experience and others experience is being the idea to write composition. But, there are another sources and information for discovering the ideas. Such as, the opinions people about particular subject giving evidence. The next is whom do the students ask? Someone can find out a great deal by asking other people about their experience. The next step to get the sources is going to the library. At first when one's goes into library, he may be a bit confused. It is hard to know where to begin. Most libraries have card catalogues. After someone got his ideas, he has to:

a. Select a Subject

- Choose a subject that someone know something about

- $\quad$ Limit the topic

- Remember the purpose of composition

b. Planning a composition

a. Make a list of ideas

b. Group the ideas under headings

c. Make an outline

The purpose of one's outline is to show all of the ideas and headings that will go into the composition in order, he will take them up and in the relation they have to each other.

\section{References}

Alice, Oshima, and Ann, Hague. 1988. Introduction to Academic Writing. Tokyo: Addison-Wesley Publishing Company

AS, Horby. 1982. Oxford Learner's Dictionary of Current English. New York: Oxford University Press. 
John E., Warriner. 1977. English Grammar and Composition. Second Course. New York: Harcourt Brace Jovanovich.

Lexy, Moleong. 1983. Metodologi Penelitian Kualitatif. Jakarta: Depdikbud.

Mc., Crimmon. 1984. Writing With Purpose. New Jersey Palo Alto: Hougthon Mifflin Company.

Viki, King. 2003. Menulis Skenario Dalam 21 Hari. Jakarta: Aku Baca.

Wilga M., Rivers. 1981. Teaching Foreign Language Skills. London: The University of Chicago Press. 